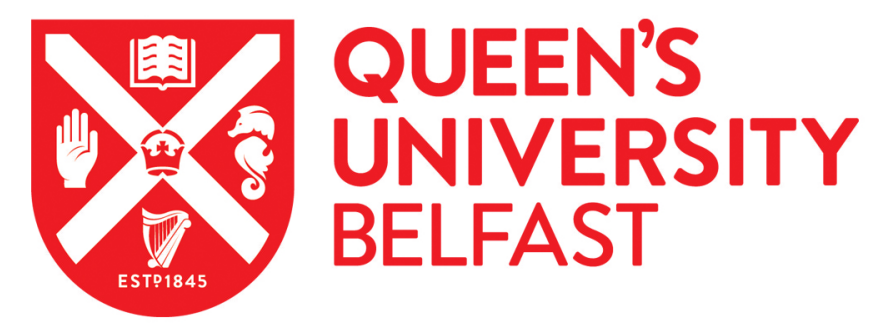

\title{
Towards a Contingency Theory perspective of Quality Management in Enabling Strategic Alignment
}

McAdam, R., Miller, K., \& McSorley, C. (2016). Towards a Contingency Theory perspective of Quality Management in Enabling Strategic Alignment. International Journal of Production Economics.

https://doi.org/10.1016/j.ijpe.2016.07.003

Published in:

International Journal of Production Economics

Document Version:

Peer reviewed version

Queen's University Belfast - Research Portal:

Link to publication record in Queen's University Belfast Research Portal

Publisher rights

(c) 2016. This manuscript version is made available under the CC-BY-NC-ND 4.0 license (http://creativecommons.org/licenses/by-nc-nd/4.0/), which permits distribution and reproduction for non-commercial purposes, provided the author and source are cited.

\section{General rights}

Copyright for the publications made accessible via the Queen's University Belfast Research Portal is retained by the author(s) and / or other copyright owners and it is a condition of accessing these publications that users recognise and abide by the legal requirements associated with these rights.

Take down policy

The Research Portal is Queen's institutional repository that provides access to Queen's research output. Every effort has been made to ensure that content in the Research Portal does not infringe any person's rights, or applicable UK laws. If you discover content in the Research Portal that you believe breaches copyright or violates any law, please contact openaccess@qub.ac.uk. 


\section{Author's Accepted Manuscript}

Towards a contingency theory perspective of quality management in enabling strategic alignment

Rodney McAdam, Kristel miller, Carmel McSorley

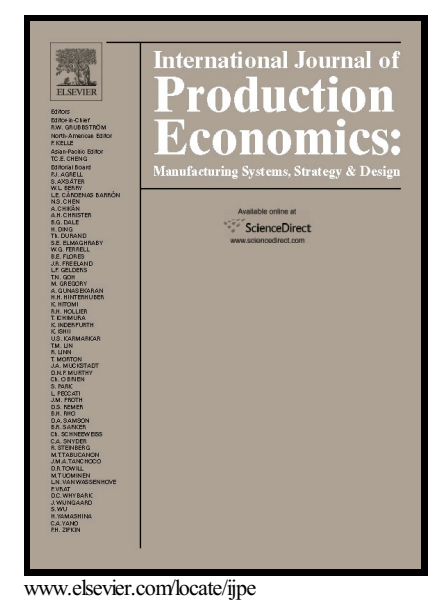

PII: $\quad$ S0925-5273(16)30139-6

DOI: $\quad$ http://dx.doi.org/10.1016/j.ijpe.2016.07.003

Reference: PROECO6459

To appear in: Intern. Journal of Production Economics

Received date: 29 June 2015

Revised date: 14 June 2016

Accepted date: 3 July 2016

Cite this article as: Rodney McAdam, Kristel miller and Carmel McSorley Towards a contingency theory perspective of quality management in enablini strategic alignment, Intern. Journal of Production Economics http://dx.doi.org/10.1016/j.ijpe.2016.07.003

This is a PDF file of an unedited manuscript that has been accepted fo publication. As a service to our customers we are providing this early version o the manuscript. The manuscript will undergo copyediting, typesetting, an review of the resulting galley proof before it is published in its final citable form Please note that during the production process errors may be discovered whic could affect the content, and all legal disclaimers that apply to the journal pertain 


\title{
ACCEPTED MANUSCRIPT
}

Towards a Contingency Theory perspective of Quality Management in Enabling Strategic Alignment

Author details:

Professor Rodney McAdam

Ulster Business School

Ulster University

UK

BT37 0QB

Email r.mcadam@ulster.ac.uk

Dr Kristel miller

Queens university Belfast

Email kristel.miller@qub.ac.uk

Carmel McSorley

Ulster University

Email cmcsorley@improveyourbusiness.org

\begin{abstract}
The aim of this paper is to explore the role of Quality Management (QM) theory and practice using a contingency theory perspective. The study is grounded in the role of QM in improving strategic alignment within Small and Medium Sized Enterprises (SMEs) using Contingency Theory rather than adopting best practice approaches. An inductive theory building research methodology was used involving multiple case analyses of five SMEs, involving repeat
\end{abstract}




\section{ACCEPTED MANUSCRIPT}

interviews ( $n=45)$, focus groups $(n=5)$ and document analysis. From the findings, it was found that Contingency Variables (strategy, culture, lifecycle and customer focus) and their respective typologies were found to interact with $\mathrm{QM}$ practices in helping to shape strategic alignment between the SMEs and their environments. This shaping process based on contingency approaches occurred in a manner unique to each SME and their respective environments rather than in an overarching best practice manner.

Key words: Quality Management; Contingency theory; Strategic Alignment; SMEs; Case Studies.

\section{Introduction}

Contingency theory suggests that "organisational effectiveness results from fitting characteristics of the organisation.....to contingencies that reflect the situation of the organisation" (Donaldson, 2001, p 1). Typical contingencies (known as contingency variables, Langfield-Smith, 2007) including for example strategy (O'Regan and Ghobadian, 2006) and culture (Sousa and Voss, 2008). From this perspective organisations seek to improve their performance by improving fit and alignment with their defined set of contingency variables and hence the changing external environment. This process of fit is viewed as a dynamic and ongoing process especially in fast moving business environments (Daft et al, 2010; Donaldson, 2006; Burns and Stalker, 1961). Contingency theory is especially useful when there is a lack of an established overarching theoretical framework (Simpson et al., 2012; De Clercq et al., 2014) with an emphasis on contextually grounded approaches based on contingency fit rather than a single best way to manage an organisation (Donaldson, 2001).

This exploratory study seeks to make a contribution to Quality Management (QM) using a contingency theory perspective applied to a contemporary business issue. The business issue within which to ground the contingency theory perspective on QM is that achieving and 


\section{ACCEPTED MANUSCRIPT}

maintaining strategic alignment within Small and Medium Sized Enterprises (SMEs) in rapidly changing business environments. Corley and Gioia (2011) and Ridder et al. (2014) suggest exploratory theory building studies should commence their contribution to theory by identifying a key problem in organisational practice that is both current and which requires future development. Corley and Gioia (2011) refer to this approach as theory focusing on the pragmatic aspects of a problem or phenomena, which in this paper is the role of QM in relation to strategic alignment in SMEs. The issue of strategic alignment is a challenge for SMEs in fast changing markets (Simpson et al., 2012; Raymond and St-Pierre, 2013; Bagnoli and Giachetti, 2015). Moreover, $\mathrm{Ng}$ et al (2015) suggest the need for further research into aligning QM efforts with the external environment. Rauniar et al. (2008:133) defines strategic alignment as "the extent to which a firm's overall business, product, and technology guide the product development contents and processes". Atrophy of strategic alignment in SMEs can lead to a lack of market and customer focus, and loss of competitiveness (Brown et al., 2007; Garg and Goyal, 2012; Bagnoli and Giachetti, 2015), failed product/service launches with delayed time to market (Simpson et al., 2012), increased technology misalignment problems with higher costs due to misused technology resources (Kock and Strotmann, 2006) and lack of agility in key markets (Alpkan et al., 2007). Moreover, the default representation of SMEs as scalar versions of large organisations or "little big firms" (Tilley, 2000:33) oversimplifies the contextual issues driving strategic alignment in SMEs. For example, some QM studies on SMEs refer to Quality Management Systems (QMS) and fail to recognise the informal and broader approaches to QM practices used to drive alignment within SMEs as noted by Garengo et al. (2005) and Bititci et al. (2012). Hence, we focus on QM practices and their effect on strategic alignment in SMEs, which can be viewed as informal versions of QMSs. 


\section{ACCEPTED MANUSCRIPT}

The lack of an overarching theoretical framework addressing the role of QM practices in strategic alignment has led to the emergence of contingency based approaches (Jusoh and Parnell, 2008; Sousa and Voss, 2008; Simpson et al., 2012; De Clercq et al., 2014). Here, QM practices that drive or orchestrate strategic alignment are viewed as contingent upon a range of contingency variables $(\mathrm{CVs})$. This contextual approach leads to grounded studies rather than prescriptive best practice solutions in QM theory and practice, where Srinivasan and Bryan (2014) suggest that best practice and rule based approaches to QM are not as effective as more contextually grounded approaches which address quality culture. Similarly, Dubey and Gunasekaran (2015) refer to this approach in exploring the more people orientated aspects of QM. Jayaram et al (2010) suggest the use of contingency theory in contrast to universalist approaches to QM. We suggest that the contingency theory approach is appropriate in exploring how QM practices in SMEs can be used to improve strategic alignment as defined by Rauniar et al., (2008). Accordingly, the aim of the paper is to explore the role of QM practices in improving strategic alignment within SMEs using a contingency theory approach. To focus the study, service sector SMEs have been selected, where Gunaselaran and Ngal's (2012) review suggest that operations management has an increasing service focus. This selection helps in avoiding the dominance of large manufacturing operating assumptions present in manufacturing related SME studies (Hultman and Shaw, 2003; Garengo and Biazzo, 2013). It also addresses the paucity of studies on strategic alignment in service sector SMEs.

The paper is structured as follows; first, we consider Strategic Alignment, QM practices and Contingency theory. This section is followed by the formulation of our research questions and methodology adopted. Next, the results and discussion section further develops the conceptual framework and the development of empirically grounded propositions. Finally, the paper 


\section{ACCEPTED MANUSCRIPT}

concludes with the contribution to theory in relation to QM and the implications for practice and recommendations for further research.

\section{Literature:}

\section{Strategic Alignment, QM practices and Contingency theory}

Having identified the SME strategic alignment problem or phenomena as the starting point of the QM theory building study, there is a need for contingency-based theory building (referred to as stage 1) to show how QM practices can influence strategic alignment. This approach is consistent with Gioia and Pitre's (1990) definition of theory as a statement of concepts and their interrelationships that show how, or why, a phenomenon occurs. Contingency theory has emerged as a lens for exploring the links between strategic alignment and QM practices (Garg and Goyal, 2012; Raymond and St-Pierre, 2013) and first requires the identification of a number of contingency factors or variables $(\mathrm{CVs})$. These $\mathrm{CV}$ s can only be changed in the long term and with considerable effort (Sousa and Voss, 2008; Raymond and St-Pierre, 2013) and are related to QM practices through a process of dynamic alignment (Johnston and Pongatichat, 2008) as shown in the initial conceptual framework (Figure 1).

\section{Figure 1 about here}

Figure 1 shows the need to identify a set of CVs that are that are appropriate to the context of the phenomena being explored as suggested by Raymond and St-Pierre (2013) and LangfieldSmith (1997). Second, each CV is represented by an appropriate typology (Figure 1). Third, changes to the CVs (e.g. external market or technology changes) as represented by these typologies require the need for dynamic alignment using orchestrating QM practices as shown in Figure 1. The underlying assumption of Figure 1 is that $\mathrm{CVs}$ and their typologies need to be context specific (Johnston and Pongarichat, 2008; Raymond and St-Pierre, 2013; De Clercq et al., 2014) and that bundles of QM practices should be used in the alignment process as shown 


\section{ACCEPTED MANUSCRIPT}

in Figure 1 (Raymond and Croteau, 2009). Hence, the concept of QM "off-the-shelf" universal best practices that are considered relatively independent of context, is questioned (Sousa and Voss, 2008; Sousa and Aspinwall, 2010). Somewhat counter-intuitively for innately resource limited SMEs, it is suggested that the development of QM practices in driving strategic alignment is idiosyncratic and contextual (Garengo et al., 2005; Bititci et al., 2006; Raymond and St-Pierre, 2013). QM practices in this SME context are informal versions of QMSs based on the application of QMS models which include inter alia models such as ISO 9000, the Business Excellence Model, Baldrige Model, Lean Value Streaming, and Benchmarking amongst others.

\section{CVs and CV Typologies}

The generic rules derived from extant research for selecting the CVs in Figure 1 state that they should be relatively independent and be the main influence on QM practices (Sousa and Voss, 2008; Langfield-Smith, 1997). They should also be exogenous to the managers responsible for QM practices (Bititci et al., 2006) and should only be influenced, to a very limited degree (i.e. high inertia), by changes in the QM practices (Martin-Pena and DiazGarrido, 2008). Overall, one should be parsimonious in selecting CVs to avoid overt interdependencies (Martin-Pena and Diaz-Garrido, 2008). Bititci et al. (2006) and Raymond and Bergeron's (2008) set of contingency variables for QM-based alignment studies in SMEs were found to be representative of the SME-based CVs in the literature and therefore were initially adopted and modified to reflect the SME service sector context of this study. Raymond and Bergeron (2008) suggest that this parsimonious approach helps in identifying both the effects of the CVs and in identifying the need for further CVs due to unexplained effects on the QM practices. Table 1 (for refereeing purposes) shows the literature table used in deriving the CVs for this study. 


\section{ACCEPTED MANUSCRIPT}

\section{Table 1 about here}

Hence, the four CVs were selected based on these selection rules, current context and as supported in other studies in the literature as shown in Table 1 and Figure 1, namely strategy, culture, lifecycle and customer focus CVs.

The representative CV typologies, or Gestalts, shown in Figure 1, that are used to represent and contextualise CVs, tend to be borrowed from a range of fields as a priori constructs for inductive theory building (Langfield-Smith, 1997). Thus, the contribution to theory in contingency studies includes systematically borrowing topologies for each of the CVs and integrating them in a coherent manner within a conceptual framework, rather than creating new typologies (Agarwal and Hoetker, 2007; Corley and Gioia, 2011) and is consistent with Gioia and Pitre's (1990) definition of theory. The typologies for each of the four CVs are now discussed. First, in relation to using strategy as a CV, a number of QM practice-based studies use the established Miles and Snow (1978) strategy typology. These studies include those of Langfield-Smith (1997), O’Regan and Ghobadian (2006) and Daft (2007). This typology helps to represent strategic intent as a starting point for strategic alignment using driving QM practices consistent with Johnston and Pongatichat's (2008) approach.

\section{Figure 2 about here}

Figure 2 shows the four different categories of the Miles and Snow (1978) typology are: Defender - emphasis on efficiency and cost reduction to maintain existing markets; Analysers - simultaneous focus on maintaining and growing existing markets while seeking out new markets to sustain and increase growth; Prospectors - a focus on new service and market opportunities to drive growth as opposed to the duality of the Analysers; Reactor - no clear strategy with a tendency to react to market changes in a lag manner. O'Dwyer et al. (2009) suggest that any expression of strategy within service based SMEs may be formal or informal and that informality should not be interpreted as paucity thereof. Second, in relation to 


\section{ACCEPTED MANUSCRIPT}

organisational lifecycle CV a number of studies probe lifecycle effects on SMEs (Garengo et al, 2007; Nair and Boulton 2008). These studies indicate that using lifecycle as a CV overcomes the limitations of organisational size or age, which can often mask dynamic lifecycle and growth effects (Raymond and Bergeron, 2008). Life-cycle models typically incorporate five stages (Greiner, 1972; Churchill and Lewis, 1983). The Greiner lifecycle model (Figure 2) was adopted for the current study as a result of a critique by Garengo et al. (2007) which supports its applicability in a wide range of SME studies at varying stages of growth.

\section{Figure 3 about here}

Figure 3 shows Greiner's (1972) lifecycle stage model which suggests that organizations go through five stages of growth: Phase One - growth through creativity: a preparatory search phase of identifying matching resources and opportunities; Phase Two - growth through direction: procedures provide direction through a functional structure; Phase Three - growth through delegation: decentralised decision making gives more autonomy; Phase Four - growth through co-ordination: decision makers operate freely but the organisation maintains overall control; Phase Five - growth through collaboration: use of teams and networks to accomplish tasks. The model also reflects an increasing level of formality in an SME's modus operandi as it progresses through the lifecycle stages (Figure 3).

Third, the inclusion of Customer Focus as a CV (Figure 1) reflects the service context of the current study and is consistent with that of O'Dwyer et al. (2009) and Hultman and Shaw's (2003) studies of service-based SMEs. These studies reflect the customer facing emphasis within service-based SMEs, consistent with Heinske and Davis's (2006) call for studies on customer alignment within service operations management (SOM) studies. Ng et al. (2007) suggest a typology for customer focuses of three key elements, namely: Professional Services; Service Shops and Mass Services, as shown in Figure 4. 


\section{ACCEPTED MANUSCRIPT}

\section{Figure 4 about here}

These categories relate to the levels of customer contact and customer numbers. Professional Services have a high degree of customer contact with high elements of customisation and process, front office operations and low volumes of customers. Mass Customisation types have high customer volumes but low contact time, customisation and an emphasis on back office operations. Service Shops have medium levels of customer contact, customer numbers, and customisation (Silvestro, 2001). Hultman and Shaw's (2003) study of QM in service SMEs suggest there will be a transactional - relational continuum response to a customer focus typology. Transactional actions involve larger customer numbers and less customer contact time. Relational covers in-depth relationships at personal and organisational levels (O'Dwyer et al., 2009). Hence, the customer focus typology, should consider both transactional and relational issues in interpreting the role of QM practices in supporting strategic alignment as shown in Figure 4.

Fourth, culture is defined as a CV in Sousa and Voss (2008), Storey and Hughes (2013) and Bititci et al.'s (2006) studies of QM. Continuing with the concept of borrowing from other fields, consistent with Corley and Gioia's (2011) and Ridder et al. (2014), it is suggested that Handy's (1985) culture typology, as shown in Figure 5, is appropriate. Although somewhat dated, it has maintained considerable traction in the literature (Brindley, 2005; Bititci et al. 2006; Sousa and Voss, 2008).

\section{Figure 5 about here}

The culture typology has four elements. Role culture: focus on procedure, hierarchy and status; Power culture: dominant and authoritative person in charge with mainly informal rules; Achievement culture: task and purpose orientated with a can-do participatory orientation; and Support culture: empowered environment with high levels of intrinsic motivation. Thus, as shown in Figure 5, there is increased task definition in the Role and Achievement types or 


\section{ACCEPTED MANUSCRIPT}

quadrants and increased empowerment in the Support and Achievement types or quadrants. Therefore, as shown by Hultman and Shaw (2003) and O'Dwyer et al. (2009), culture, as interpreted by the different elements of this typology, is likely to have a differential effect on strategic alignment and QM practices in service-based SMEs.

\section{QM, Dynamic alignment and Research Questions}

Following the discussion on the CVs, typologies and QM practices within the organisation (Johnston and Pongatichat, 2008), strategic alignment is viewed as a dynamic process over time (Figure 1). Here, the level of alignment atrophies unless there is an intervention which implies that a state of perfect alignment rarely exists (O'Regan and Ghobadian, 2006; Raymond and Croteau, 2009; Raymond and St-Pierre, 2013). This dynamic approach to the process of alignment is referred to as "the dynamic process of adjusting to environmental change and uncertainty" (Miles and Snow, 1978:3). Therefore, as stated in Raymond and Bergeron's (2008: 590) study of contingency in SMEs - "alignment cannot be prescribed in a universal fashion" but involves consideration of contextual contingencies as in this study. As shown by Jusoh and Parnell (2008), Johnston and Pongatichat (2008) and Garengo et al. (2007) organisations often use a range or bundle of QM practices (e.g. relating to informal elements of TQM, ISO 9001; Business Excellence Framework (BEM), Baldrige Model and Balanced Scorecards) to orchestrate the process of alignment between CVs and QM practices (Figure 1). However, Machuca et al. (2006) claims there is a paucity of research in this area, particularly in an SME service operations context. The aforementioned discussion and Figure 1 resulted in the following interrelated research questions:

RQ1: What is the relationship and level of alignment between the contingency variables and the development and implementation of QM practices in service based SMEs? 


\section{ACCEPTED MANUSCRIPT}

RQ2: How can these relationships be represented in a series of working propositions to guide alignment of QM practices for each of the contingency variables?

RQ3: What is the contribution of contingency theory to further developing QM theorisation?

In sum, stage 1 of the study has led to the development of an initial conceptual framework and identification of the research questions. In stage 2, these research questions are used to guide the empirical exploration, further development of the conceptual framework and the development of empirically grounded propositions.

\section{Research Methodology}

In seeking to address the aim and research questions, an inductive theory building approach was adopted consistent with Barratt and Oke (2007), Perren and Ram (2004), and Sousa and Voss (2008). The a priori conceptualisations (i.e. Figures 1-5) in stage 1 of the study acted as the foundation for the empirical work of stage 2. Sousa and Voss (2008) suggest the need for QM theory building methodologies such as case research in contingency studies to build explanations and engage in a sense-making process in relation to strategic alignment. Corley and Gioia (2011) suggest that the findings should also be sense-giving in that they should suggest future directions in the field of study. Similarly, Perren and Ram (2004), Yin (2011) and Eisenhardt (1991) suggest the "how" and "what" style of the research questions is suited to this type of interpretative research philosophy. In this approach multiple sources of data are obtained and analysed in a recursive sense making process comparing data and theory until a saturated level of understanding is achieved. This research philosophy capitalises on the rich practitioner based knowledge discourse of contingency studies and QM practices in SMEs (Perren and Ram, 2004; Garengo et al., 2007). The chosen research methodology was that of multiple case studies which is suited to the interpretive research approach (Eisenhardt, 1991; Yin, 2011). 


\section{ACCEPTED MANUSCRIPT}

\section{Table 2 about here}

Table 2 shows that five case SME organizations ${ }^{1}$ were selected from different service areas to provide a wide range of companies and perspectives. This selection also helped to create richness through the inter and intra variation of the cases. Each of the SMEs was experiencing growth based on the definition of growth at different stages of the lifecycle model (Greiner, 1972). The growth case selection criterion was chosen because SMEs facing the challenges of growth are more likely to re-examine the assumptions relating to their strategic alignment and enabling QM practices (Neely et al., 2005). Dobbs and Hamilton (2007) suggest that multiple measures should be used in defining a growth phase in relation to the lifecycle model. The selection of specific cases to meet the growth condition consisted of analysing documents and discussions with stakeholders knowledgeable of potential candidates. In particular, help was obtained from Government Development and Support Agencies and The Centre for Competitiveness $^{2}$.

For each of the five chosen cases, semi-structured interviews $(n=9$ for each case i.e. 45 interviews in total for all cases) were held with the Managing Director (or equivalent) and members of the management team for each case SME. The areas covered in the semistructured interviews were based on the initial conceptual model of Figure 1 as summarised in Appendix 1. The repeat interview technique adopted enabled a relationship of trust (Yin, 2011). All interviews lasted between 1 and 2 hours and were taped, transcribed and coded. After the interviews, focus groups $(n=5)$ each lasting between 1 and 1.5 hours were held with each of the case organizations comprising of the Managing Director (or equivalent) and the

\footnotetext{
1 The cases fit within the EU definition of SMEs (EU SME guide (http://ec/europa.eu/enterprise policy (sme definition/index en.htm).

${ }^{2}$ An SME based private sector, not for profit, membership organisation endorsed by the Department of Enterprise, Trade and Investment.
} 


\section{ACCEPTED MANUSCRIPT}

management team i.e. one focus group per case organization. Each focus group for each SME was facilitated by a one member of the research team and concentrated on key issues raised in the interviews. Other data sources obtained for each case organization included a range or organizational documents including each Case's QM BEM Self-Assessment submission document (based on company Quality Award submissions), company reports, Government funding reports, and minutes of meetings.

The data analysis followed Radnor and Boaden's (2004) method for analysing interpretive research involving interviews, focus groups and case data. First, the data from the different sources were synthesised based on consensus amongst the research team. Second, the researchers used an open inductive coding approach as suggested by Miles and Huberman (1994) where literature and empirical findings were juxtaposed, compared and contrasted using the initial conceptual framework (Figure 1) as an initial building block. Third, the emergent themes and sub-themes from this coding process were then used by the research team to develop evidence tables (Tables 3 and $4 a-4 d$ ) so as to present the findings in a logical manner, consistent with Miles and Huberman (1994). Fourth, repeat interviews, emails and telephone calls were used to clarify outstanding issues. These four steps were used in a recursive sense making and theory building manner as suggested by Yin (2011).

In terms of limitations the exploratory nature of the study makes exact replication of the study difficult. Rather the study should be viewed as a basis for helping to conceptually shape further related studies involving contingency theory and SMEs (Yin, 2011). Moreover, the theory building approach adopted within the paper will require further studies to develop theory testing based on the current findings (e.g. such as in cross sectional analysis). Limitations also include the focus being solely on SMEs, where larger organisations may be driven by a different range of factors which may be sectoral in nature. 


\section{ACCEPTED MANUSCRIPT}

\section{Results and Discussion}

The results and discussion sections (stage 2) are combined, due to the qualitative case-based and exploratory approach to the research (Eisenhardt, 1991; Yin, 2011). The structure of this section is based on discussing the alignment between the QM practices and each of the $\mathrm{CV}$ typologies in relation to the research questions. This approach is consistent with Donaldson (2006, p 23) who refers to this dynamic alignment process as achieving "quasi fit" rather than exact fit. The findings are summarised in evidence tables derived from the research data analysis as suggested by Miles and Huberman (1994). These evidence tables include Table 3 which shows the $\mathrm{CV}$ and corresponding typology placing for each of the five cases and Tables 4a-4d which show the key QM practices driving strategic alignment in relation to each $\mathrm{CV}$ typology for each of the five cases. Based on these findings and a synthesis of the literature two main working propositions were developed for each CV (i.e. eight in total), the first of each being more generic relating to the literature and the second being more specific relating to the main empirical work.

\section{Evidence Table 3 about here}

\section{Evidence Tables $4 a-4 d$ about here}

Two subsections for each CV are shown. First, a subsection based on the evidence tables for a given $\mathrm{CV}$ and its strategic alignment dynamics (or process of achieving "quasi fit" Donaldson, 2006, p23) are discussed for each of the 5 cases. Next, a subsection for this CV covers the cross case analysis and development of the propositions. These two subheadings are repeated for each of the $4 \mathrm{CVs}$.

\section{Strategy CV and alignment dynamics}




\section{ACCEPTED MANUSCRIPT}

Case 1 was operating in the highly competitive economy hotel and tourism sector and sought to increase competitiveness using standardised operational procedures for room bookings and feedback. As noted by Case 1's Managing Director "Contact is made with the customer after each event to check on performance and get feedback.... whether it was a one-off problem or a process issue." To improve efficiency, Case 1 also had a high level of vertical integration with suppliers (e.g. food and specialist event management functions). Potential new entrants were mainly economy based international hotel chains. Hence, in relation to the strategy CV, Case 1 was in the Defender category of Miles and Snow's typology (Figure 2, evidence Table 3). The data and documentation analysis showed Case 1 used a bundle of QM practices including informal elements of an integrated Business Excellence Model (BEM) and Balanced Scorecard (BSC), Investors in People (IiP) QM Framework and a service industry sector award model. However, as confirmed in the focus group, lead performance measures (or forward facing predictive performance measures) were not sufficiently used in shaping QM practices (such as the new service offerings based on market changes) reflecting the Defender strategy approach (Table 3). Benchmarking practices were in-sector (i.e. hospitality) as opposed to out of sector as shown in evidence Table 4a and led to efficiency savings rather than innovation-based market alignment. These findings for Case 1 concur with Daft et al's (2010) conceptualisation of a simple and stable environment where mechanistic conditions prevail (based on Burns and Stalkers, 1961, idealised types). In the mechanistic type knowledge is seen as residing at the top of the organisational structure with hierarchical control and limited empowerment (Daft et al, 2010).

Cases 2 and 4 were classified as Analysers (Figure 2; evidence Table 3). The focus was on maintaining growth in their traditional transport services (e.g. road haulage) while increasing growth in new markets in terms of "green" based transport alternatives: "We have a review of 


\section{ACCEPTED MANUSCRIPT}

sales per division [i.e. by Analyser category] in a transactional manner which leads to a review of a wide range of performance measures" (Case 2 Operations Manager). Case 4 also had a traditional focus on construction services but also developed new markets in providing services for sustainable developments. The Sales Manager (Case 4) stated, "the MD [Managing Director] meets with customers each week at director level to ensure all areas of the business are covered....we put a lot of time into this and expect to see performance measurement processes put in place." The respective focus groups for these cases showed that this duality or Analyser "balance" (Raymond and Bergeron, 2008; Simons, 1987) was reflected in the QMS and QM practices used by these cases. For example, the interviews showed that Case 2 used finance and process QM and practices and measures which addressed the traditional side of the business e.g. profit, turnover, sales, fixed and recurring costs, delivery time and load planning. The development of the "green" market involved using lead measures such as carbon equivalents for operations and costs per alternative energy source, which were incorporated into QM practices involving scanning for new technology, benchmarking and analysing potential markets. Similarly, the new business side in Case 4 was driven by lead QM measures such as heat retention for new materials and cost saving practices in terms of waste generation measures. Overall, Cases 2 and 4 had high levels of flexibility to maintain both sets of market conditions as found by Raymond and Croteau (2009) in relation to Analysers (Figure 2). Flexibility is also a characteristic of more organic organisations where employees have higher levels of empowerment to enable them to address increasingly complex environments and customer requirements (Daft et al, 2010; Burns and Stalker, 1961).

Case 3 and 5 were classified as Prospectors (Figure 2; evidence Table 3) which reflected new market opportunities to drive growth as opposed to the duality of the Analysers (Jusoh and Parnell, 2008; Raymond and Bergeron, 2008). This focus was reflected in the predominance 


\section{ACCEPTED MANUSCRIPT}

of lead QM measures and associated QM practices for these cases (evidence Table 4a). These findings were consistent with that of O'Regan and Ghobadian (2006). Case 3 used software development and licensing to design and offer new services. Typical lead QMs (evidence Table 4a) related to innovation, which was mainly based on the BSC and addressed market trends, technology effectiveness, and return on investment and training. Consistent with Neely et al (2005) Case3's MD suggested the need to increase lead QM practices to drive alignment, "current performance measures allow us to know if there is a problem today so it can be corrected tomorrow, rather than finding out at the end of the year." Case 5 was similar to Case 3 in that their provision of business services sought out new markets to drive growth: "The customer has to be number one.... we emphasise to staff it is the quality of the call to potential customers, not just the number of calls - they need to prepare well" (Case 5 Managing Director). This approach reflected that of a more organic organisational structure with an emphasis on empowerment and a recognition that employees at all levels could supply knowledge in addressing complex and variable customer needs (Daft et al, 2010).

\section{Strategy CV and alignment dynamics - cross case and propositions}

A cross case analysis in relation to the dynamics of alignment for the strategy $\mathrm{CV}$ found that a dynamic process of change was observed in relation to alignment (Figure 1). The interviews and focus groups showed that within the cases there was a dynamic which involved trying new QM practices, developing modifications, and discarding obsolete ones as part of the alignment process. Moreover, across the cases a bundle of QM practices was used in various degrees of informality in a continuously changing manner. With increased complexity of customer need and the need for more dynamic organisational response there was a move from mechanistic to organic organisational structure consistent with Daft et al (2010) and Donaldson (2001). At a micro level, these dynamics can be interpreted as strategic alignment 


\section{ACCEPTED MANUSCRIPT}

legitimising processes in overcoming normative resistance of the status quo (Suchman, 1995; Johnson, 2004). Each case, when seeking to improve strategic alignment by using QM practices faced innate resistive forces which are based on comparing new QM measures and practices against existing organisational norms, routines and practices (Grey and Willmott, 2010). For example, in Case 4 employees did not initially support such QM practice based changes due to a lack of understanding of the new strategy where the managers did not adequately communicate strategic alignment challenges or train employees in the new methods in a timely manner. Similarly, in Cases 2 and 4 belated efforts were made to improve communication and introduce training to drive lead or predictive QM practices as shown in evidence Table 4a. The findings showed that the alignment based legitimation process was time consuming (Grey and Willmott, 2010) involving formative debate, opinion forming and critical reflection relating to the need for the new or modified QM practices (Grey and Willmott, 2010), which are consistent with an organic organisational structure adapting to increasingly complex organisational environments (Donaldson, 2001; Donaldson, 2006). The cross case analysis also showed that unlike Cases 2 and 4, those of cases 1, 3 and 5, the respective Defender and Prospector categorisations had a more single focus than the duality of the Analysers (evidence Tables 3 and 4a). The resultant alignment dynamic for these categories were therefore mainly at the operational levels with an emphasis on either an efficiency or mechanistic focus (Defender) or organic and innovation focus (prospector). Based on these cross case findings for the strategy $\mathrm{CV}$ and the process of strategic alignment, two initial working propositions (P1 and P2) are suggested. First, based on the a priori literature discussion and the initial interviews:

P1: An SME's approach to strategy and the level of informality or formality by which it is expressed, will affect the development and implementation of QM practices to achieve strategic alignment. 


\section{ACCEPTED MANUSCRIPT}

Second, based on the empirical evidence:

P2: A service based SME's approach to strategy alignment will require increased use of more advanced lead-based QM measures and practices for the more organic Analyser and Prospector categories in comparison to the mainly standard documentation-based or more mechanistic lag QM measures and practices of the Reactor and Defender categories.

\section{Culture CV and alignment dynamics}

Case 1 was classified as having a Role culture (Figure 5; evidence Table 3) reflecting a focus on procedure and hierarchy with defined roles consistent with a more mechanistic organisational structure located within a relatively simple and stable environment (Daft et al, 2010; Donaldson, 2001). The findings (evidence Table 4b) showed this hierarchy was reflected in a cascade approach to QM practices where formalised QM measures were devised by management and transmitted downwards to all levels relying on training needs analysis and Investors in People (IiP) cascade approaches. The lack of empowerment led to suboptimal QM practices being applied as found by Bititci et al. (2006) in relation to Role cultures and QM translation in SMEs, coupled with employee coping mechanisms to circumvent the imposition (Johnston and Pongatichat, 2008). The interviews showed that efforts to improve QM practices such as room turnaround between guests and provision of outside contractors for special events had to rely on imposed QM measures which were too generic (e.g. overall cycle time, recurrent cost and quality check list measures) when more precise and contextualised QM measures were needed to improve efficiency at a localised level.

Cases 2 and 3 were analysed as having Power cultures (Figure 5; evidence Table 3). The interviews showed that these cases had strong leaders with a knowledge of, and influence on, all levels within the organisations which is characteristic of Power cultures. In Case 2 


\section{ACCEPTED MANUSCRIPT}

(Transport) the Managing Director had led the company since its inception and continued to have a hands-on role. However, his reliance on his tacit knowledge resulted in a lack of formal QM practices to drive strategic alignment. The management team had a tendency to "check with the boss" (Case 2, Operations Manager) which is a characteristic of Power cultures (Bititci et al., 2004). Similarly, in Case 3 (Software and Licensing), the Managing Director was a technical expert in software design and also tended to impose an informal QM practice approach based on his tacit knowledge as shown in evidence Table 4b. Case 3's Engineering Manager, in referring to QM practices noted, "We use are own versions based on the MD's [Managing Director's] experience rather than off the shelf approaches." The drive for new business compounded this informal and tacit approach where new services were developed without clear strategic alignment. Thus there is a challenge for managers when moving from relatively simple to more complex and faster moving business environments to move the organisational structure and QM approaches from mechanistic to more organic approaches as suggested by Donaldson (2006).

Case 4 (Construction Services) had an Achievement culture (Figure 5, evidence Table 3) with a task and purpose orientated approach combined with a "can-do" or organic participatory attitude (evidence Table 4b). The mainly professional employees (e.g. Engineers, Surveyors and Architects) and the multifunctional nature of the Case 4 business services projects (such as design and build) suited the participatory approach of the Achievement culture (Bititci et al., 2006). The interviews and case documentation showed that the Achievement culture was reinforced by a focus on employee development QM practices. As noted by Case 4's Sales Manager, "We put a lot of time into this which is reflected in our use of, and compliance with, ISO 9001:2000, ISO 9014 and ISO 18000 Standards and practices."

Case 5 (Business Services) had a Support culture consistent with more organic organisational characteristics (Figure 5, evidence Table 3) emphasising empowerment and high levels of 


\section{ACCEPTED MANUSCRIPT}

intrinsic motivation, with a focus on developing new services for new and existing markets. The interviews and focus group showed that employees at all levels were encouraged to develop ideas for improving and developing new services. "We try to get staff to be more aware of what is going on around them - new developments, new investments, local unemployment rates, what is on the news etc." (Case 5- Managing Director). This approach led to continuous change of $\mathrm{QM}$ practices with a commensurate lack of formalised approaches (i.e. low task definition - Figure 5) as shown in evidence Table 4b. For example, efforts to apply the BEM and IiP were marginalised due to the fast moving baseline measures and the degree of bureaucracy these models were seen as imposing.

\section{Culture CV and alignment dynamics - cross case and propositions}

The focus group findings showed that Cases 2 and 3 (Power culture) and Case 5 (Support culture) strategic alignment was based on more tacit and informal QM practices while those cases with Role culture (Case 1) and Achievement Culture (Case 4) had a more rigid and formalised approach to using QM practices to achieve strategic alignment. Overall, the findings for the culture contingency variable led to the following two propositions. First, based on the literature and initial interviews:

P3: The prevailing culture typology, Role, Power, Achievement or Support cultures, within a service-based SME will influence the implementation of strategic alignment-based QM practices.

Second, based on the empirical evidence:

P4: A service-based SME's approach to culture will have more informal and tacit approaches in the use of QM practices to support strategic alignment for those SMEs in the Power and Support culture categories, in comparison to those SMEs in the Role and Achievement categories which have more emphasis on documented and advanced QM practices. 


\section{Lifecycle CV and alignment dynamics}

Case 1 (Hotel and Tourism) was at Stage 5 of the Lifecycle model (Figure 3; evidence Table 3) where QM measures and QM practices reflected a networked organisation achieving a level of maturity and consistent growth (Greiner, 1972). The interviews showed that QM practices were established with clearly defined procedures. As noted by Case 1's Managing Director, "We use a broad range of customer measures and processes starting with meeting and exceeding customer expectations..... at the start you may think that financial measures are the most important but then you realise that without the customer focus you cannot develop the business." However, the focus group showed that a limitation of this engraining process was the lack of agility in responding to innovation opportunities in the marketplace, where new sets of QM practices were required leading to the redundancy of some existing QM measures and QM practices. These developments reflect the need to move from mechanistic to organic organisational structures when the business environment becomes increasingly complex (Daft et al, 2010; Donaldson, 2006) with commensurate changes in QM practices.

Towards the other end of the Lifecycle model, Cases 2 and 3 were at Stage 2 (Figure 3, evidence Table 3) with an emphasis on growth through leadership. For example, in Case 2 the interviews showed that there was a focus on developing new greener modes of transport services leading to new QM measures and QM practices which were less established and defined but which addressed the new emerging marketplace (e.g. QM measures such as carbon equivalents and QM practices such as scanning for new technology). Similarly, the focus group showed that Case 3 grew new markets using licensing of software services which led to a search for, and adaption of, new QM practices. These findings are consistent with the Pioneer strategy type analysis for Case 3 with the commensurate establishment of a more organic organisational structure. 
Cases 4 and 5 mapped onto the middle region of the Lifecycle model i.e. Stages 4 and 3 respectively (Figure 3, evidence Table 3). Stage 3 emphasises growth through delegation which was consistent with Case 5's development of QM measures and QM practices to empower employees (Greiner, 1972) consistent with an organic organisational structure (Daft et al, 2010). Stage 4 emphasises growth through increased coordination (Nair and Boulton, 2008). Here, the interviews and case documentation showed Case 4 had a project-based approach to design and build in their traditional markets and a more bespoke approach for their new renewable markets through coordination with customers and suppliers. Their QM measures and QM practices were not as formal as those of Case 1 as shown in evidence Table 4c.

The interview and focus group data for Case 1 revealed a need to develop QM practices to support increased agility and to overcome normative resistance from well-established approaches which reflected plateau states within the Lifecycle progression. A lack of out of sector benchmarking tended to reinforce the status quo with minor changes rather than improving strategic alignment. Cases 2, 3, 4 and 5 were located in lower stages i.e. Stages 2-4 (Figure 3; evidence Table 3) focusing on directed growth following the establishment of the firm. Here, management drove the implementation of innovation orientated QM practices with more focus on customer measures and empowered employees to meet customer expectations. The strategic alignment forces were focused on the need to grow and the need to adopt a more organic organisation structure and approach to QM practices which could address more complex market dynamics rather than relying on traditional markets which were being eroded (Johnson, 2004).

\section{Lifecycle CV and alignment dynamics - cross case and propositions}




\section{ACCEPTED MANUSCRIPT}

In relation to the dynamics of alignment between the Lifecycle $\mathrm{CV}$ and the $\mathrm{QM}$ practices, the cross case findings showed that in the earlier or lower stages of the Lifecycle model (i.e. Cases 2, 3, 4 and 5) QM practices were more fluid and could accommodate innovation (evidence Table 4c) consistent with more organic organisational structures (Daft et al, 2010). However, at the latter Stages such as 4 and 5 (Case 1) the relative rigidity of established QM practices (i.e. becoming more mechanistic due to organisational growth problems where the initial entrepreneurial approach is diminished) could potentially limit opportunities from market and technology innovation ultimately leading to misalignment as the market place continues to develop (Sousa and Voss, 2008). Hence, legitimation of new or modified QM practices in overcoming normative resistance may take longer as an organisation progresses through the lifecycle model. These cross case findings for the lifecycle CV and the dynamic process of alignment suggest two further propositions (P5 and P6) Firstly, based on the a priori literature discussion and the initial interviews:

P5: An SME's development and implementation of QM practices to achieve strategic alignment will vary according to its respective lifecycle stage.

Second, building on the empirical evidence:

P6: A service based SME's Lifecycle categorisation will lead to increased rigidity and a more mechanistic approach to growth-based QM practices for strategic alignment as the SMEs progress towards the latter stages of the lifecycle model.

P6 suggests there is a significant challenge for SMEs to achieve growth while avoiding the dangers of becoming more mechanistic in structure, especially in more complex and fast changing markets.

\section{Customer Focus CV and alignment dynamics}




\section{ACCEPTED MANUSCRIPT}

Case 1 (Hotel and Tourism) was in the Mass Services category of Customer Focus (Figure 4; evidence Table 3). There was a focus on increasing customer numbers through efficiency consistent with the Mass Services type (Ng et al., 2007), which reflects the more mechanistic Defender placing (Daft et al, 2010). Use of QM practices, as shown in evidence Table 4d, included elements of IiP, BEM and hospitality sector award models. The continuous improvement algorithm within these models aligned with the ongoing service enhancement across a large number of customers. However, the focus group showed that the BEM SelfAssessment Quality Award documentation was limited due to its innate large manufacturing organisation language (e.g. assuming an organisation with established hierarchical and divisional structures). Customer QM practices were more transactional than relational (e.g. room occupancy levels and room turnaround times and practices) reflecting Silvestro (2001) and Hultman and Shaw's (2003) findings that Mass Services type primarily focus on transactional dealings with customers.

Cases 3 and 4 were in the Professional Services category (Figure 4; evidence Table 3) with a focus on the unique value proposition offered, i.e. Design and Build software services in Case 3 and construction services in Case 4. The emphasis was on relational customer QM practices. For example, Case 3 had a small number of large customers where relational QM practices included practices for partnering with suppliers and customers and other stakeholders (including regulators) in developing software licenses. Case 3's Managing Director noted the need for further QM quantification, "We meet product user groups and suppliers and report qualitatively, we need to develop more quantitative measures, however we are not quite there yet." This approach is consistent with Case 3's Pioneer strategic intent with an emphasis on moving towards a more responsive organic structure as suggested by Daft et al (2010). Case 5 (Integrated Business Services) and Case 2 (Transport) were in the Service Shop category (Figure 4, evidence Table 3) where the emphasis was on the duality of the business, i.e. the 


\section{ACCEPTED MANUSCRIPT}

traditional business, which was mainly transactional in terms of QM practices and the new or emergent part of the business which was more relational in nature. The interviews showed that transactional QM measures included cost effectiveness per tonnage delivered while relational measures included networking levels with "green" stakeholders in the travel industry. Case 5's Operations Manager noted that the improved use of transactional QM practices, "helped with the ISO [ISO: 9000:2008] and business excellence applications [BEM] and the Balanced Scorecard [BSC] which helps when submitting tenders to large companies."

\section{Customer Focus CV and alignment dynamics - cross case and propositions}

In relation to the alignment dynamics between the Customer Focus CV and the QM practices based on the cross case comparisons, all of the cases (1-5) showed evidence of both relational and transactional customer-based QM practices in the alignment process. The Professional Service Cases (3 and 4) placed more emphasis on building relational-based customer QM practices than Mass Services (Case 1) and Service Shop cases (Cases 2 and 5) (evidence Tables 3 and 4d). The main legitimation drivers were customer needs awareness at all levels in the SMEs.

Based on these findings P7 and P8 are suggested. Firstly, based on the a priori literature discussion:

P7: An SME's approach to customer focus in terms of Professional Services, Service Shops or Mass Services types will influence its development and implementation of strategic alignment-based QM practices, including both transactional and relational approaches. Next, based on the empirical evidence:

P8: A service-based SME's Customer Focus categorisation will result in QM practices, which support strategic alignment, being more relational and organic based than transactional 


\section{ACCEPTED MANUSCRIPT}

(or more mechanistic) for the Service Shop category in contrast to the Mass Services category.

\section{Revised conceptual framework}

In seeking to revise the conceptual framework we suggest the following three overall findings that guide this revision. First in more simple and stable environments where a mechanistic organisational structure prevails QM practices tend to be simpler and standardised. Second, when the business environment becomes more complex and dynamic with commensurate moves towards a more responsive and organic structure then QM practices tend to be more advanced with increased adaptability to any given context. Third there is a need for flexibility in approaches to QM practices when firms such as fast growing SMEs necessitate a dynamic shift from mechanistic to more organic structures in increasingly complex business environments.

Building on these three macro findings in relation to RQ3, the cross case analysis, based on the empirical results and discussion, including evidence Tables 3 and $4 \mathrm{a}-4 \mathrm{~d}$, have led to the conceptual framework of Figure 1 being further elaborated with two main clarifications as shown in Figure 6.

\section{Figure 6-Revised Conceptual Framework about here}

First, the propositions (P1-P8) developed from the interaction between the CV typologies and the QM practices have been added and are shown as key determinants of the QM practices adopted to drive strategic alignment in a "quasi fit" manner (Donaldson, 2006, p23). Second, the dynamics of the alignment process between the CV typologies and the QM practices have been clarified to show the iterative steps of alignment evaluation and identifying new, modified or redundant QM practices as the organisation is challenged to move from simple to 


\section{ACCEPTED MANUSCRIPT}

complex environments and from mechanistic to more responsive organic structures. In this micro process of legitimation QM practice alignment drivers are challenged by the normative resistance of the status quo (Johnston, 2004; Suchman, 1995). These enhancements to the conceptual framework further emphasise the contextually embedded and idiosyncratic nature of strategic alignment, consistent with Jayaram et al (2010) and Srinivasan and Kurey (2014), which is counterintuitive to best practice solutions.

\section{Conclusions and Recommendations}

The conclusions in the paper are based on the development of contingency theory and the conceptual framework arising from the analysis of the results (from the interviews and focus groups) and synthesising these with the literature critique as shown in the results and discussion sections. From these findings and discussions it is concluded that in more simple and stable environments QM practices tend to be more simple and standardised and the organisational structure is more mechanistic in nature. Alternatively, when the business environment becomes more dynamic and increases in complexity QM practices tend to be more complex or advanced with an emphasis on adaptability to any given context rather than a one size fits all. This approach is more suited to an organic organisational structure (Daft et al, 2010). Moreover, it is concluded from the findings and discussion that strategic alignment in SMEs requires a complex and context based approach involving contingency theory and QM practices which is counter-intuitive to innately resource limited SMEs using readily available "off -the-shelf" QM best practice approaches to improve strategic alignment. The findings and discussion show that this response is more consistent with the organic organisation structure as suggested by Donaldson (2001). Thus we conclude, consistent with Srinivasan and Kurey (2014), Jayaram et al (2014) and Dubey and Gunasekaran (2015), that QM must move beyond solely best practice and rule based approaches which are limited to 


\section{ACCEPTED MANUSCRIPT}

relatively stable environments and more mechanistic organisational structures. The relationships between the CVs (as expressed by typologies (Figures $1-5$ ) as addressed in the findings and discussion were found to dynamically interact with QM practices in shaping strategic alignment to achieve "quasi fit" (Donaldson, 2006, p23) in a contextual and hence contingent manner within the SMEs. In relation to RQ1, it is concluded that these relationships are complex and contextual and hence applying overarching best practice mantras will be insufficient to sharpen and focus QM practice applications in driving strategic alignment, especially in complex and fast moving environments. The proposition development in relation to RQ2 essentially builds on the conceptualisation framework (arising from the results and discussion). These propositions (P1-P8) aid in shaping QM practices to drive strategic alignment which in turn create future research agendas. Moreover, the process of legitimisation was helpful in seeking to explain the dynamics of contingent alignment between CVs and QM practices at a micro level as shown in Figure 6 (Suchman, 1995; Johnson, 2004).

Overall, the paper makes a contribution to theory by exploring a key pragmatic organisational problem or phenomena, namely strategic alignment, using a theory building approach based on developing the conceptualisation of QM-based contingency theory with CV typologies borrowed from other fields of study, consistent with Ridder et al. (2014) and Corley and Gioia's (2011) review of approaches to theoretical contributions. The explanatory power of contingency theory in relation to QM is expanded, as suggested by Corley and Gioia (2011), by incorporating mechanistic and organic organisational types located within both simple and stable and that of more complex and dynamic environments. Moreover, the empirical study has grounded the theory in the SME context, an area in which there is limited contingency theory development. In regard to generalizability, the conceptual framework of Figure 6 (in 


\section{ACCEPTED MANUSCRIPT}

response to RQ3) and the development of working propositions (1-8) offer theoretical generalizability rather than direct application or repeatability in other contexts, which is consistent with Gioia and Pitre (1990) and Ridder et al. (2014). Hence the study acts as a basis for both further conceptual and empirical studies in other organisational contexts (e.g. different sectors).

It is recommended that the study could be further developed along three avenues. First, a larger number of cases from different service sectors could be researched leading to a context specific set of CVs and QM practices and new or further refined propositions. This suggestion would extend the scope of the research and further test the robustness of the findings and lead to specific findings for a given sector. Second, this approach could be used in leading to the development of both taxonomies and typologies of cases in relation to strategic alignment in SMEs. Further empirical case data would help in establishing typologies which can act as a basis for further contingency theory-based research studies. Third, the propositions could be further developed and refined into hypotheses and measurement scales as part of a QM-based cross-sectional theory testing study leading to further refinement of the theoretical arguments. This initial study in relation to the aim and research questions is viewed as supplying contingency-based conceptualisation and empirical case-based evidence which can act as a basis for developing such quantitative studies.

From a practice perspective reflective practitioners need to move beyond applying archetypal best practice $\mathrm{QM}$ practices in a prescriptive manner to contribute to strategic alignment studies in resource limited SMEs. The development of the Contingency approach and propositions suggests a broad template that reflective practitioners can contextualise and specify to address the alignment context which they are seeking to address. Here practitioners 


\section{ACCEPTED MANUSCRIPT}

must be prepared to change QM practices in line with increasingly complex and dynamic

environmental change and as organisations move from mechanistic to more responsive and

organic structures. Thus, the case-based QM practices can act as practical initial guides for

SMEs seeking to develop aligned QM practices in driving strategic alignment.

\section{References}

Agarwal, R., Hoetker, G., 2007. A Faustian Bargain? The growth of management and its relationship with related disciplines. Academy of Management Journal 50, 304-1322.

Alpkan, L., Yilmaz, C., and Kaya, N., 2007. Market Orientation and Planning Flexibility in SMEs. International Small Business Journal 25, 52-172.

Bagnoli, C., Giachetti, C., 2015. Aligning knowledge strategy and competitive strategy in small firms, Journal of Economics and Management 16, 571-598.

Barratt, M., Oke, A., 2007. Antecedents of supply chain visibility in retail supply chains: A resource-based theory perspective. Journal of Operations Management 25, 1217-1233.

Bititci, U., Garengo,, P., Dörfler, V., and Nudurupati, S., 2012. Performance Measurement: Challenges for Tomorrow. International Journal of Management Reviews 14, 305-327.

Bititci, U., Mendibil, K., Nudurupati, S., Garengo, P., Turner, T., 2006. Dynamics of performance measurement and organisational culture. International Journal of Operations and Production Management 26, 1325-1350.

Brown, S., Squire, B., Blackmon, K., 2007. The contribution of manufacturing strategy. Journal of Operations and Production Management 27, 282-302.

Burns, T. and Stalker, G.M., 1961. The management of innovation, Tavistock, London.

Churchill, N. C., and Lewis, V.L., 1983. The five stages of small business growth. Harvard Business Review 3, 30-50.

Corley, K.G., Gioia, D.A., 2011, Building Theory About Theory Building: What Constitutes a Theoretical Contribution? Academy of Management. The Academy of Management Review 36, 12-32.

Daft, L., Murphy, J. and Willmott, H. 2010. Organization theory and design. South Western, NY.

Donaldson, L. 2001. The contingency theory of orgqanizations. Sage, London.

Donaldson, L. 2006, The contingency theory of organizational design: challenges and opportunities in Organizational design: The evolving state of the art by (eds) Burton, R.M., Eriksen, B., Hakonsson, D.D. and Snow, C.C.

De Clercq, D., Thongpapanl, N., Dimov, D., 2014. Contextual ambidexterity in SMEs: the roles of internal and external rivalry. Small Business Economics 42, 191-205.

Dobbs, M., Hamilton, R.T., 2007. Small business growth: recent evidence and new directions. International Journal of Entrepreneurial Behaviour \& Research 13, 296-322.

Dubey, R., Gunasekaran, A., 2015, Exploring soft TQM dimensions and their impact on firm performance: some exploratory empirical results, International Journal of Production Research 53, 371-382.

Eisenhardt, K. M., 1991. Better stories and better constructs: The Case for rigor and comparative logic. Academy of Management Review 16, 620-627. 


\section{ACCEPTED MANUSCRIPT}

Garengo, P., Biazzo, S., 2013. From ISO quality standards to an integrated management system: an implementation process in SME. Total Quality Management \& Business Excellence 24, 310-319.

Garengo, P., Bititci, U., 2007. Towards a contingency approach to performance measurement: an empirical study in Scottish SMEs. International Journal of Operations \& Production Management 27, 802-825.

Garengo, P., Biazzo, S., Bititci, U., 2005. Performance measurement systems in SMEs: A review for a research agenda. International Journal of Management. Reviews 7, 25-47.

Garg, A., Goyal, D.P., 2012. Striving towards strategic alignment in SMEs: an empirical analysis. Journal of Advances in Management Research 9, 77-95.

Gioia, D.A., Pitre., E., 1990. Multiparadigm Perspectives on Theory Building, Academy of Management. The Academy of Management Review 15, 584-595.

Greiner, L., 1972. Evolution and revolution as the organisation grows. Harvard Business Review 50, 37-46.

Grey, C., Willmott, H., 2010. Critical Management Studies: A Reader. Oxford University Press, London.

Gunasekaran, A., Ngai, E.W.T., 2012, The future of operations management: An outlook and analysis, International Journal of Production Economics 135, 687-701.

Handy, C., 1985. Understanding organisations, Penguin, London.

Hultman, C., Shaw, E., 2003. The interface between transactional and relational orientation in small service firm's marketing behaviour: A study of Scottish and Swedish small firms in the service sector. Journal of Marketing Theory and Practice 11, 36-51.

Jayaram, J., Ahire, S.L., Dreyfus, P., 2010, Contingency relationships of firm size, TQM duration, unionization, and industry context on TQM implementation - A focus on total effects, Journal of Operations Management 28, 345-356

Johnson, C., 2004. Introduction: Legitimacy processes in organisations. Sociology of Organisations 22, 1-24.

Johnston, R., Pongatichat, P., 2008. Managing the tension between performance measurement and strategy: coping strategies. International Journal of Operations and Production Management 28, 941-967.

Jusoh, R., Parnell, J., 2008. Competitive strategy and performance measurement in the Malaysian context: An exploratory study. Management Decision 46, 5-31.

Langfield-Smith, K., 1997. Management control systems and strategy: a critical review. Accounting, Organisations and Society 22, 207-232.

Machuca, J., Gonzalez-Zamora, M., Aguilar-Escobar, V., 2006. Service Operations Management research. Journal of Operations Management 25, 585-603.

Martin-Pena, M., Diaz-Garrido, E., 2008. Typologies and taxonomies of operations strategy: a literature review. Management Research News 31, 200-218.

Miles, M., and Huberman, A., 1994. Qualitative data analysis, Beverly Hills, CA.

Miles, R., Snow, C., 1978. Organizational strategy, structure, and process. McGraw-Hill: New York, NY.

Nair, A. and Boulton, W., 2008. Innovation-orientated operations strategy typology and stagebased model. International Journal of Operations and Production Management 28, $748-771$.

Neely, A., 2005. The evolution of performance measurement research. International Journal of Operations and Production Management 25, 1264-1277.

Ng, S., Russell-Bennett, R., Dagger, T., 2007. A typology of mass services: the role of service delivery and consumption purpose in classifying service experiences. Journal of Services Marketing 21, 471-480. 


\section{ACCEPTED MANUSCRIPT}

Ng, S.C.H., Rungtusanatham, J.M., Zhao, X., Ivanova, A., 2015, TQM and environmental uncertainty levels: profiles, fit, and firm performance, International Journal of Production Research 53, 4266-4286

O'Dwyer, M., Gimore, A., and Carson, D., 2009. Innovative marketing in SMEs. European Journal of Marketing 43, 46-61.

O'Regan, N., Ghobadian, A., 2006. Perceptions of generic strategies of small and medium sized engineering and electronics manufacturers in the UK. Journal of Manufacturing Technology Management 17, 603-620.

Perren, L., Ram, M., 2004. Case-study method in small business and entrepreneurial research Mapping boundaries and perspectives. International Small Business Journal 22, 83100.

Radnor, H., 2001. Researching your professional practice: doing interpretive research, OU Press, London.

Radnor, Z., Boaden, R., 2004. Developing an understanding of Corporate Anorexia. International Journal of Operations and Production Management 24, 424-440.

Rauniar, R., Doll, W., Rawski, G. Hong, P., 2008. The role of heavyweight product manager in new product development. International Journal of Operations \& Production Management 28, 130-154.

Raymond, L., Bergeron, F. 2008. Enabling the business strategy of SMEs through e-business capabilities; a strategic alignment perspective. Industrial Management and Data Systems, 108. 577-595.

Raymond, L., Croteau, A., 2009. Manufacturing strategy and business strategy in mediumsized enterprises: performance effects of strategic alignment. IEEE Transactions on Engineering Management 56, 192-201.

Raymond, L., St-Pierre, J., 2013. Strategic capability configurations for the internationalization of SMEs: A study in equifinality. International Small Business Journal 31, 82-102.

Ridder, H., McCandless, B., Hoon, C., 2014. Entering a Dialogue: Positioning Case study Findings Towards Theory British Journal of Management 25, 373-387.

Silvestro, R., 2001. Towards a contingency theory of TQM in services. International Journal of Quality and Reliability Management 18, 254-288.

Simons, R. 1987. Accounting control systems and business strategy: an empirical analysis. Accounting, Organizations and Society, 12, 357-374.

Simpson, M., Padmore, J., Newman, N., 2012. Towards a new model of success and performance in SMEs. International Journal of Entrepreneurial Behaviour \& Research $18,264-285$.

Sousa, R., Voss, C., 2008. Contingency research in operations management. Journal of Operations Management 26, 697-713.

Sousa, S., Aspinwall, E., 2010. Development of a performance measurement framework for SMEs. Total Quality Management \& Business Excellence 21, 475-494.

Srinivasan, A., Kurey, B., 2014, Creating a Culture of Quality, Harvard Business Review, April, 23-25.

Storey, C., Hughes, M., 2013. The relative impact of culture, strategic orientation and capability on new service development performance. European Journal of Marketing 47, 833-856.

Suchman, M., 1995. Managing legitimacy: strategic and institutional approaches. Academy of Management Review 20, 571-610.

Tilley, F., 2000. Small Firm Environmental Ethics: How Deep Do They Go? Business Ethics: European Review 9, 31-41. 


\section{ACCEPTED MANUSCRIPT}

Yin, R., 2011. Case study Research: design and methods. Sage Publications: Newbury Park, CA.

\section{Appendix No 1 - Semi structured Interview and Focus Group Template discussion themes}

Dependant on the question the interviewer illustrated and developed the question more fully than the summary headings listed below.

- What are the current and future challenges facing the business?

- Discuss the pace of change and rate of growth.

- What do you understand by the term alignment?

- What alignment challenges are there - past, present and future?

- How does the company address and/or measure these alignment challenges?

- What performance measures and performance measurement practices are used to help in addressing the alignment challenge?

- What is the company's approach to strategy setting?

- What type of culture is prevalent with the company?

- Where is the company in relation to life cycle development?

- What type of customer focus strategy is adopted?

- What forces help shape the performance measurement practices in driving alignment?

- What resister forces are used to limit the use of performance measurement practices in driving alignment? Give examples of new and redundant performance measurement practices in supporting alignment. 


\section{ACCEPTED MANUSCRIPT}

Figure 1 - Initial Conceptual Framework (CV = Contingency Variable)

of $\mathrm{CV}$

representation

using typologies

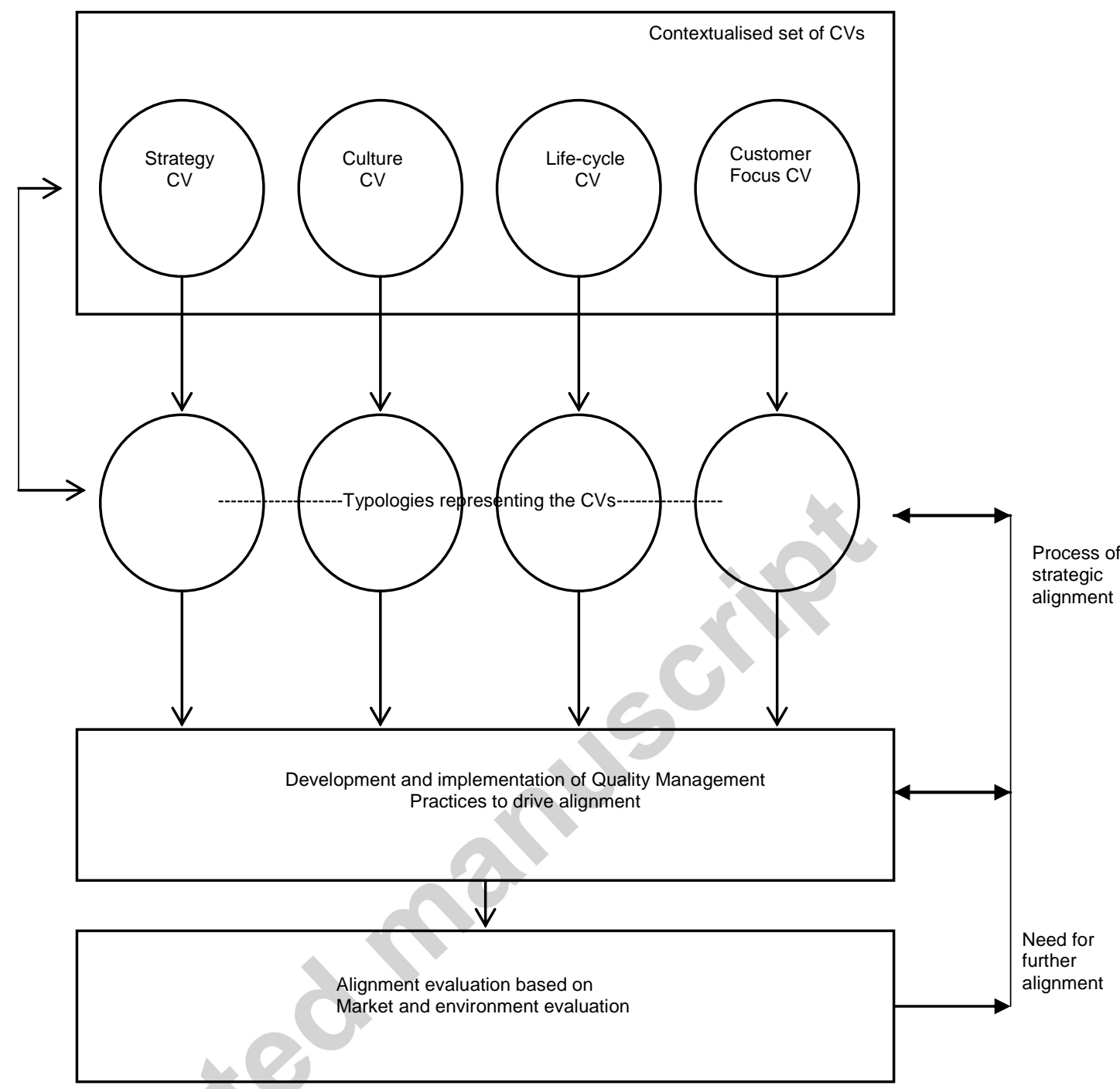

Figure 2 - Strategy Typology for Market and Environmental Uncertainty 


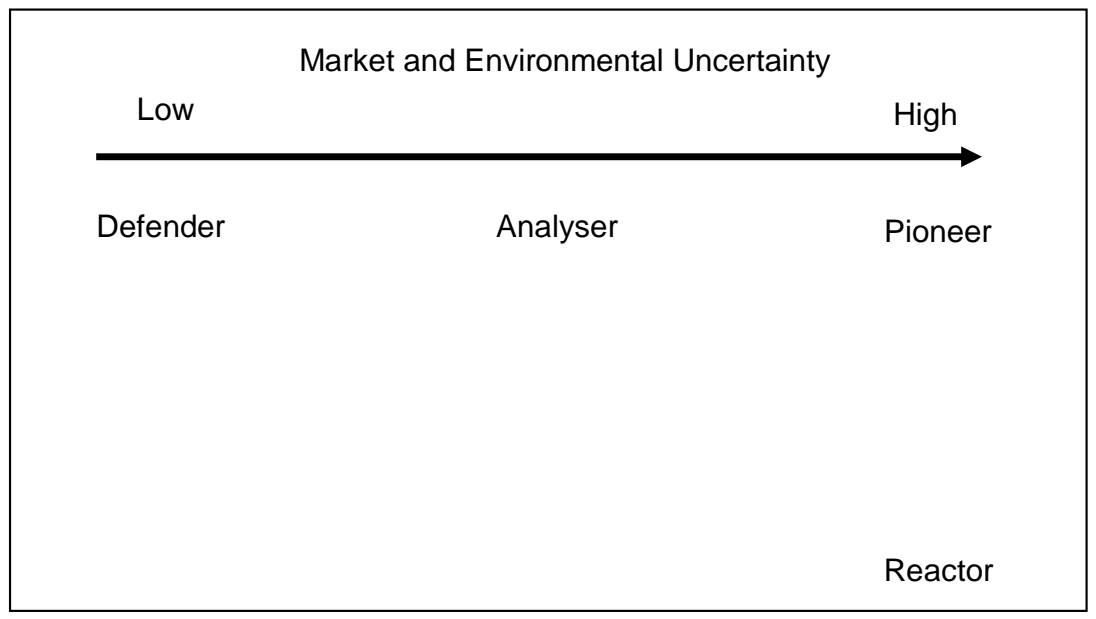


Figure 3 - Lifecycle Stage Model for organisational Growth (adapted from Greiner, 1972)

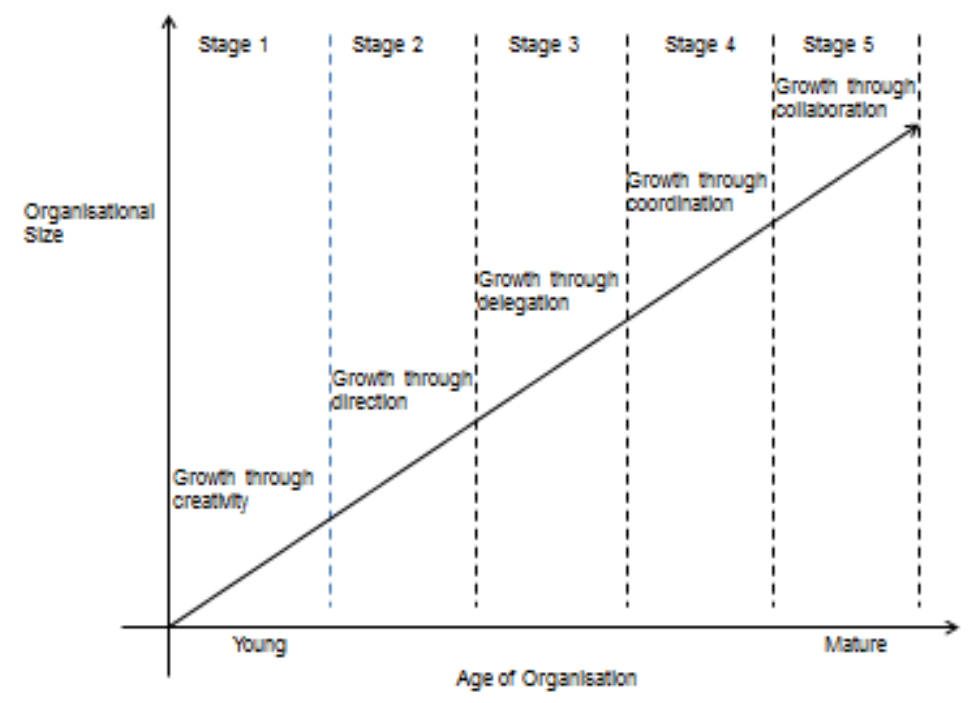


Figure 4 - Customer Focus Typology in Relation to Customer Contact and Volume of Customers

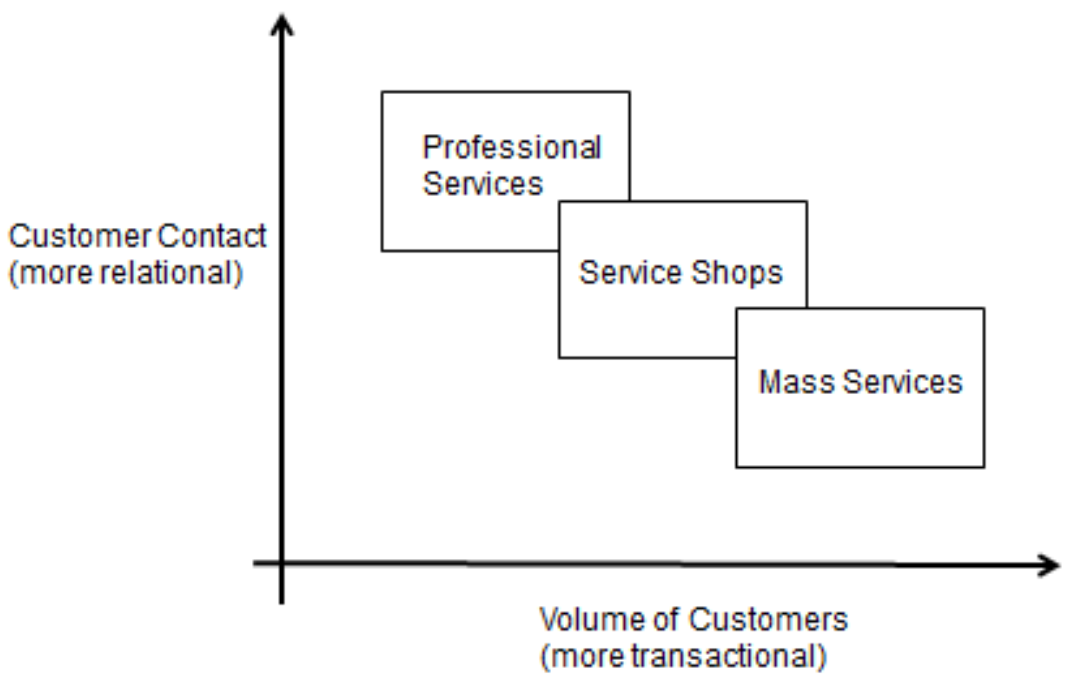


Figure 5 - Culture Typology in Relation to Empowerment and Task Definition

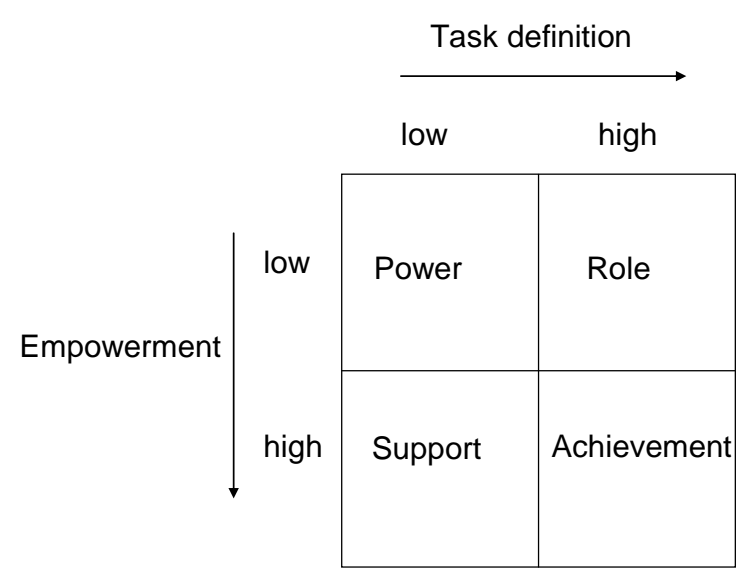


Figure 6 - Revised conceptual framework

Development

of CV

representation

using typologies

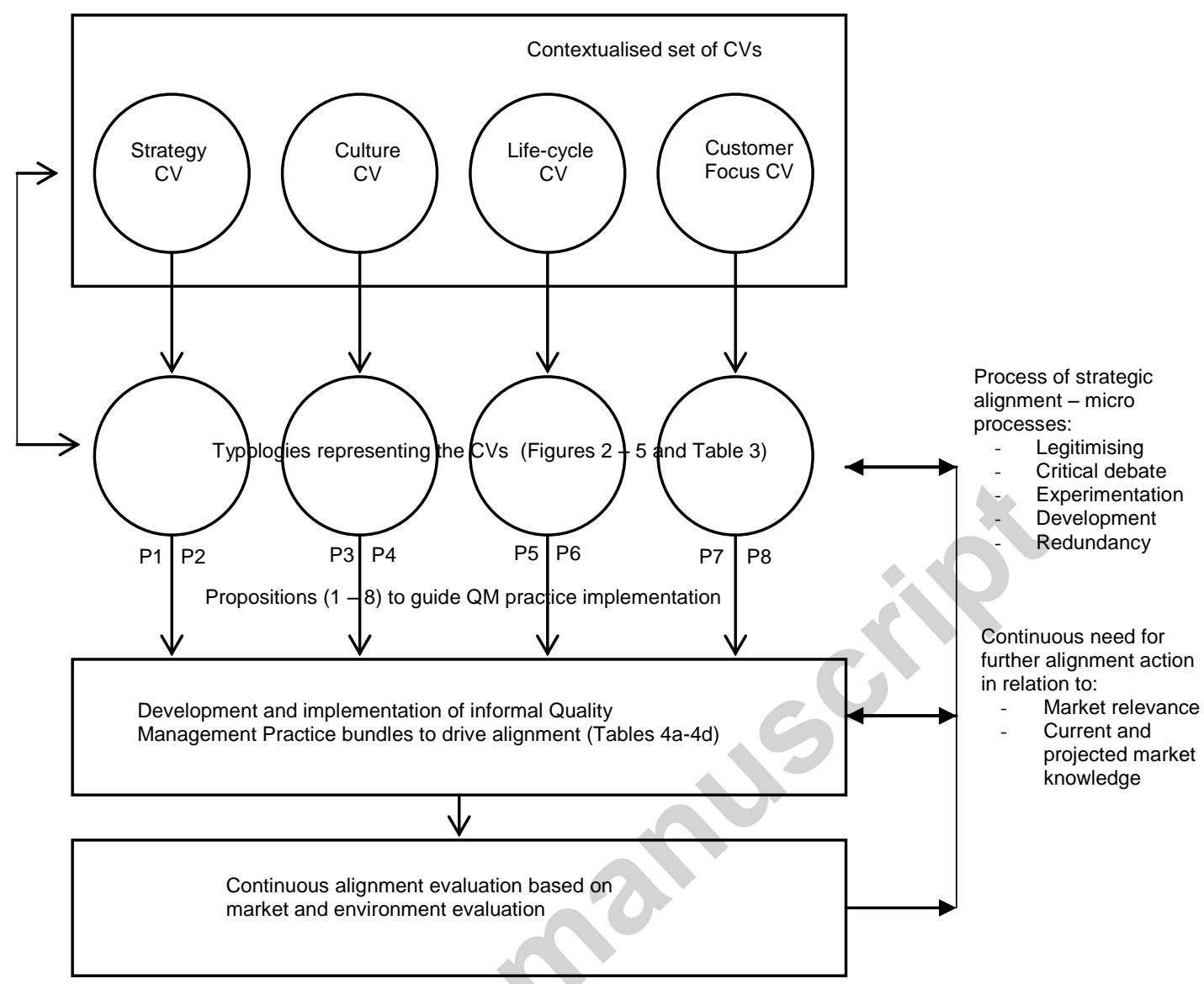

Table 1 - Contingency Variables (for refereeing purposes)

\begin{tabular}{|c|c|c|}
\hline $\begin{array}{l}\text { Contingent } \\
\text { Variable (CV) }\end{array}$ & Supporting literature & Explanation \\
\hline Strategy & $\begin{array}{l}\text { Raymond and St-Pierre } \\
\text { (2013); Raymond and } \\
\text { Bergeron (2008); Sousa and } \\
\text { Voss (2008); Heinske and } \\
\text { Davis (2006); Machuca et al. } \\
\text { (2006); Garengo and Bititci } \\
\text { (2007); Jung et al. (2009); } \\
\text { Garengo et al., 2005); } \\
\text { Lanafield-Smith (1997); }\end{array}$ & $\begin{array}{l}\text { Strategic direction within the } \\
\text { organisation is viewed as a } \\
\text { contingent variable which affects the } \\
\text { implementation of QM practices }\end{array}$ \\
\hline Culture & $\begin{array}{l}\text { Storey and Hughes (2013); } \\
\text { Sousa and Voss (2008); } \\
\text { Garengo and Bititci (2007); }\end{array}$ & $\begin{array}{l}\text { Prevailing organisation culture is } \\
\text { considered to be a contingent } \\
\text { variable which affects the }\end{array}$ \\
\hline
\end{tabular}


Garengo et al., 2005); Richie and Brindley (2005); Bititci et al. (2006)

Customer Focus Heinske and Davis (2006); Sousa (2003); Hultman and Shaw (2003); O'Dwyer et al. (2009); Garengo et al, 2005); Silvestro et al. (1992); Silvestro (2001)

Lifecycle Sjodin et al. (2011); Sharifi et al. (2006); Raymond and Bergeron (2008); Garengo et al. (2007); McAdam et al. (2010) implementation of QM practices

Within service based SMEs customer focus is viewed as a contingent variable which affects the implementation of QM practices

Organisation lifecycle positioning is considered as a contingent variable which affects the implementation of QM practices 
Table 2 - Case Summaries

\begin{tabular}{|c|c|c|c|}
\hline Case Study & Main operations & $\begin{array}{l}\text { Average } \\
\text { Number of } \\
\text { employees }\end{array}$ & $\begin{array}{l}\text { Current position and } 3 \\
\text { Year \% increase in key } \\
\text { Performance indices }\end{array}$ \\
\hline Case 1 & Hotel and Tourism & 54 & $\begin{array}{l}\text { Turnover: } £ 2,862,000 ; 17 \% \\
\text { increase. } \\
\text { Net profit before Tax: } \\
£ 270,000 ; 87 \% \text { increase. }\end{array}$ \\
\hline Case & Transport & 210 & $\begin{array}{l}\text { Turnover: } £ 36,109,000 ; \\
15.7 \% \text { increase. } \\
\text { Net profit before Tax: } \\
£ 13,603,000 ; 17.5 \% \\
\text { increase. }\end{array}$ \\
\hline Case & $\begin{array}{l}\text { Software } \\
\text { development and } \\
\text { licensing }\end{array}$ & 38 & $\begin{array}{l}\text { Turnover: } £ 2,200,000 ; \\
83.1 \% \text { increase. } \\
\text { Net profit before Tax: } \\
£ 66,000 ; 210 \% \text { increase. }\end{array}$ \\
\hline Case 4 & $\begin{array}{l}\text { Construction } \\
\text { services }\end{array}$ & 101 & $\begin{array}{l}\text { Turnover: } £ 5,100,000 ; 188 \% \\
\text { increase. } \\
\text { Net profit before Tax: } \\
£ 1,760,000 ; 220 \% \text { increase. }\end{array}$ \\
\hline Case & Business services & 20 & $\begin{array}{l}\text { Turnover: } £ 4,800,000 ; \\
71.4 \% \text { increase. } \\
\text { Net profit before Tax: } \\
£ 350,000 ; 333 \% \text { increase. }\end{array}$ \\
\hline
\end{tabular}




\section{ACCEPTED MANUSCRIPT}

Evidence Table 3 - Case typology placing in relation to Figures 2-5

\begin{tabular}{|c|c|c|c|c|c|c|c|c|c|c|c|c|c|c|c|}
\hline & \multicolumn{4}{|c|}{ Strategy } & \multicolumn{4}{|c|}{ Culture } & \multicolumn{4}{|c|}{ Lifecycle } & \multicolumn{3}{|c|}{$\begin{array}{l}\text { Customer } \\
\text { Focus }\end{array}$} \\
\hline & D & $P$ & A & $\mathrm{R}$ & $\begin{array}{l}\text { Sup } \\
p\end{array}$ & $\begin{array}{l}\text { Rol } \\
\text { e }\end{array}$ & $\begin{array}{l}\text { Pow } \\
\text { er }\end{array}$ & $\begin{array}{l}\text { Ac } \\
h\end{array}$ & $\begin{array}{l}S \\
2\end{array}$ & $\begin{array}{l}5 \\
3 \\
\end{array}$ & $\begin{array}{l}S \\
4 \\
\end{array}$ & $\begin{array}{l}S \\
5\end{array}$ & $\begin{array}{l}\mathrm{P} \\
\mathrm{S}\end{array}$ & $\begin{array}{l}S \\
S \\
\end{array}$ & $\begin{array}{l}M \\
S \\
\end{array}$ \\
\hline $\begin{array}{l}\text { Case } 1 \\
\text { (Hotel and } \\
\text { Tourism) }\end{array}$ & $\sqrt{ }$ & & & & & $\sqrt{ }$ & & & & & & $\sqrt{ }$ & & & $\sqrt{ }$ \\
\hline $\begin{array}{l}\text { Case } 2 \\
\text { (Transport) }\end{array}$ & & & $\sqrt{ }$ & & & & $\sqrt{ }$ & & $\sqrt{ }$ & & & & & $\sqrt{ }$ & \\
\hline $\begin{array}{l}\text { Case } 3 \\
\text { (Software } \\
\text { and } \\
\text { Licensing) }\end{array}$ & & $\sqrt{ }$ & & & & & $\sqrt{ }$ & & $\sqrt{ }$ & & & & $\sqrt{ }$ & & \\
\hline $\begin{array}{l}\text { Case } 4 \\
\text { (Constructi } \\
\text { on } \\
\text { services) }\end{array}$ & & & $\sqrt{ }$ & & & & & $\sqrt{ }$ & & & $\sqrt{ }$ & & $\sqrt{ }$ & & \\
\hline $\begin{array}{l}\text { Case } 5 \\
\text { (Business } \\
\text { services) }\end{array}$ & & $\sqrt{ }$ & & & $\sqrt{ }$ & & & & & & 5 & & & $\sqrt{ }$ & \\
\hline
\end{tabular}

$\mathrm{D}=$ Defender; $\mathrm{P}=$ Pioneer; $\mathrm{A}=$ Analyser; $\mathrm{R}=$ Reactor; Supp=Support; $\mathrm{Ach}=\mathrm{Achievement;}$ S1-S5= Lifecycle Stages;

PS=Professional Service; SS=Service Shop; MS=Mass Service provision. 


\section{Evidence Table 4a - Key QM practices enabling strategic alignment - in relation to the Strategy CV (Figure 2)}

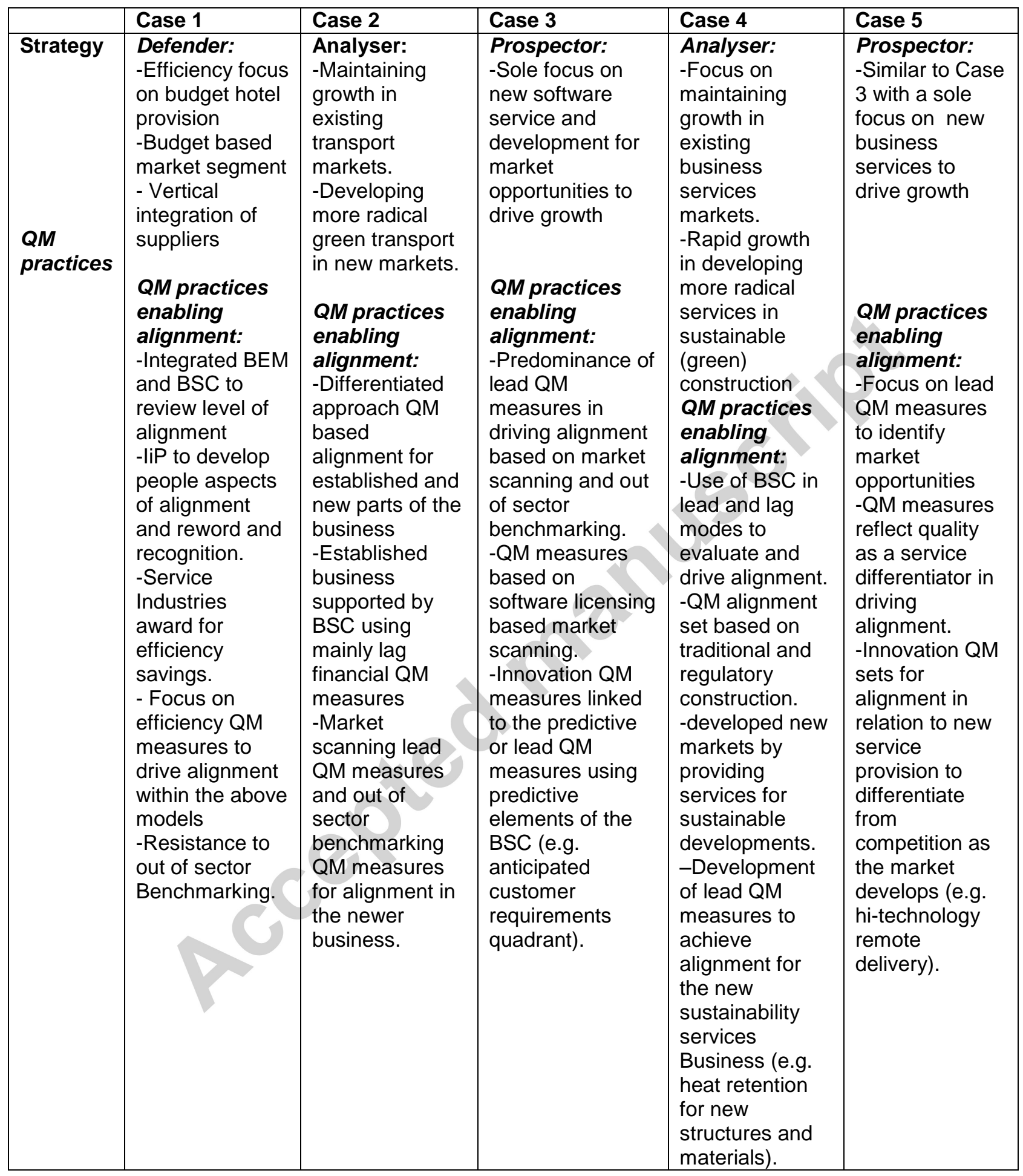

Evidence Table 4b - Key QM practices enabling strategic alignment - in relation to the Culture CV (Figure 3) 
ACCEPTED MANUSCRIPT

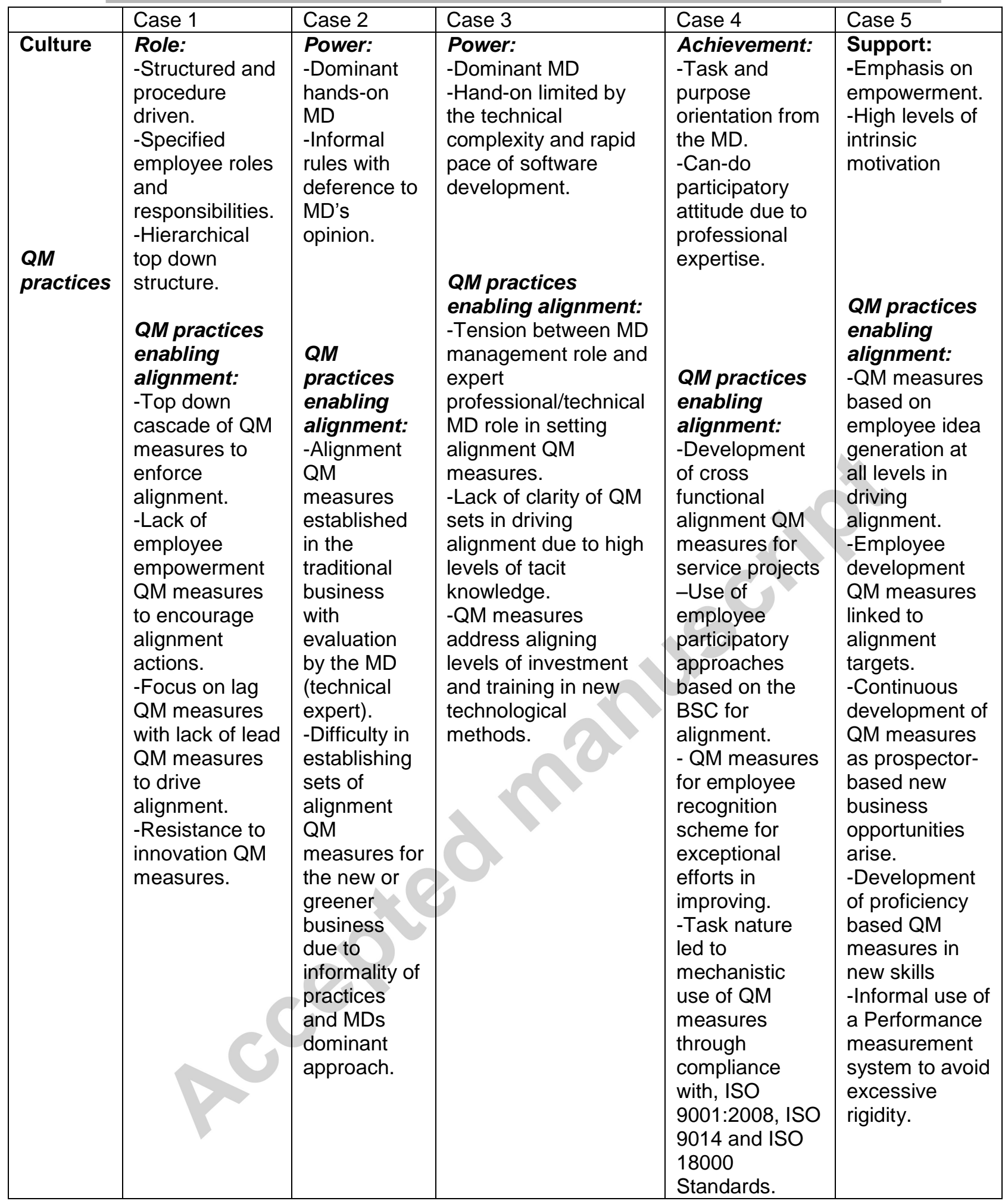

\section{Evidence Table 4c - Key QM practices enabling strategic alignment - in relation to the Lifecycle CV (Figure 4)}

\begin{tabular}{|l|l|l|l|l|l|}
\hline & Case 1 & Case 2 & Case 3 & Case 4 & Case 5 \\
\hline Lifecycle & Stage 5: & Stage 2: & Stage 2: & Stage 4: & Stage 3: \\
& - Mature & - SME & -SME becomes & -Mid region of & -Lower Mid \\
& position & becomes & established. & the Lifecycle & region of the \\
\hline
\end{tabular}


ACCEPTED MANUSCRIPT

\begin{tabular}{|c|c|c|c|c|c|}
\hline $\begin{array}{l}\text { QM } \\
\text { practices }\end{array}$ & $\begin{array}{l}\text {-Growth } \\
\text { through } \\
\text { efficiency } \\
\text { gains and } \\
\text { standardised } \\
\text { service } \\
\text { provision. } \\
\\
\text { QM } \\
\text { practices } \\
\text { enabling } \\
\text { alignment: } \\
\text {-Reliance on } \\
\text { established } \\
\text { sets of } \\
\text { efficiency } \\
\text { QM } \\
\text { measures to } \\
\text { drive } \\
\text { alignment in } \\
\text { defender } \\
\text { style } \\
\text { business }\end{array}$ & $\begin{array}{l}\text { established. } \\
\text {-Focus on } \\
\text { leadership } \\
\text { drive to } \\
\text { achieve } \\
\text { further } \\
\text { growth. } \\
\text { QM } \\
\text { practices } \\
\text { enabling } \\
\text { alignment: } \\
\text {-Focus on } \\
\text { developing } \\
\text { QM } \\
\text { measures to } \\
\text { support } \\
\text { alignment in } \\
\text { new greener } \\
\text { modes of } \\
\text { transport } \\
\text { services led } \\
\text { by the MD } \\
\text { e.g. carbon } \\
\text { equivalent } \\
\text { QM } \\
\text { measures } \\
\text { and market } \\
\text { and } \\
\text { technology } \\
\text { scanning. } \\
\text {-Lack of } \\
\text { definition of } \\
\text { alignment } \\
\text { QM } \\
\text { measures } \\
\text { due to top } \\
\text { down } \\
\text { informal } \\
\text { structure. }\end{array}$ & $\begin{array}{l}\text { QM practices } \\
\text { enabling } \\
\text { alignment: } \\
\text {-Dominant MD } \\
\text { (owner/manager) } \\
\text { role in setting } \\
\text { alignment QM } \\
\text { measures. - } \\
\text { Search for new } \\
\text { alignment QM } \\
\text { measures by } \\
\text { professional } \\
\text { software } \\
\text { developers and } \\
\text { project leaders. } \\
\text {-Focus on } \\
\text { contextual } \\
\text { alignment QM } \\
\text { measures based } \\
\text { on individual } \\
\text { large customer } \\
\text { contracts. }\end{array}$ & $\begin{array}{l}\text { model. } \\
\text {-Emphasis on } \\
\text { growth through } \\
\text { increased } \\
\text { coordination } \\
\text { (e.g. } \\
\text { involvement in } \\
\text { large } \\
\text { construction } \\
\text { projects). } \\
\text { QM practices } \\
\text { enabling } \\
\text { alignment: } \\
\text {-QM measures } \\
\text { and practices in } \\
\text { support of } \\
\text { alignment } \\
\text { becoming more } \\
\text { defined. } \\
\text {-Agility within } \\
\text { the QM } \\
\text { measures to } \\
\text { accommodate } \\
\text { the need for } \\
\text { further } \\
\text { alignment due } \\
\text { to innovations } \\
\text { in services and } \\
\text { markets (green } \\
\text { building } \\
\text { developments). }\end{array}$ & $\begin{array}{l}\text { QM Practices } \\
\text { enabling } \\
\text { alignment: } \\
\text {-Development } \\
\text { of alignment } \\
\text { QM measures } \\
\text { based on } \\
\text { employee } \\
\text { empowerment } \\
\text {-Employee } \\
\text { contributions } \\
\text { to alignment } \\
\text { QM measures } \\
\text { linked to } \\
\text { reward and } \\
\text { recognition. } \\
\text { - QM } \\
\text { measures } \\
\text { based on } \\
\text { delegated } \\
\text { authority for } \\
\text { alignment } \\
\text { improvement. }\end{array}$ \\
\hline
\end{tabular}

Evidence Table 4d - Key QM practices enabling strategic alignment - in relation to the Customer Focus CV (Figure 5)

\begin{tabular}{|c|c|c|c|c|c|}
\hline & Case 1 & Case 2 & Case 3 & Case 4 & Case 5 \\
\hline $\begin{array}{l}\text { Customer } \\
\text { Focus }\end{array}$ & $\begin{array}{l}\text { Mass } \\
\text { Services: }\end{array}$ & $\begin{array}{l}\text { Service } \\
\text { Shop: }\end{array}$ & $\begin{array}{l}\text { Professional } \\
\text { Service: }\end{array}$ & $\begin{array}{l}\text { Professional } \\
\text { Service: }\end{array}$ & $\begin{array}{l}\text { Service Shop: } \\
\text {-Median }\end{array}$ \\
\hline
\end{tabular}


ACCEPTED MANUSCRIPT

\begin{tabular}{|c|c|c|c|c|c|}
\hline $\begin{array}{l}\text { QM } \\
\text { practices }\end{array}$ & $\begin{array}{l}\text { QM } \\
\text { practices } \\
\text { enabling } \\
\text { alignment: } \\
\text {-Efficiency } \\
\text { based and } \\
\text { transactional } \\
\text { CRM to align } \\
\text { with customer } \\
\text { needs. } \\
\text { - Analysis of } \\
\text { long run QM } \\
\text { measures } \\
\text { relating to } \\
\text { internal } \\
\text { alignment of } \\
\text { increasing } \\
\text { efficiency and } \\
\text { customer } \\
\text { satisfaction }\end{array}$ & $\begin{array}{l}\text {-Reflecting } \\
\text { business } \\
\text { duality. } \\
\text {-Traditional } \\
\text { business } \\
\text { mainly } \\
\text { transactional. - } \\
\text { new or } \\
\text { emergent part } \\
\text { of the } \\
\text { business was } \\
\text { more } \\
\text { relational. } \\
\text { QM practices } \\
\text { enabling } \\
\text { alignment: } \\
\text {-Transactional } \\
\text { QM measures } \\
\text { based on } \\
\text { efficiency (e.g. } \\
\text { cost per } \\
\text { tonnage } \\
\text { delivered. } \\
\text {-Relational } \\
\text { QM measures } \\
\text { included } \\
\text { networking } \\
\text { alignment and } \\
\text { effectiveness } \\
\text { with "green" } \\
\text { clusters in the } \\
\text { transport } \\
\text { industry. }\end{array}$ & $\begin{array}{l}\text {-Emphasis on } \\
\text { unique value } \\
\text { proposition } \\
\text { (e.g. specific } \\
\text { software } \\
\text { service } \\
\text { solutions). } \\
\text {-Design and } \\
\text { build services. } \\
\text {-Smaller } \\
\text { number of } \\
\text { large } \\
\text { customers. } \\
\text { QM practices } \\
\text { enabling } \\
\text { alignment: } \\
\text {-Emphasis on } \\
\text { relational } \\
\text { customer QM } \\
\text { measures to } \\
\text { drive } \\
\text { alignment } \\
\text {-Individual } \\
\text { and contextual } \\
\text { QM sets for } \\
\text { specific } \\
\text { customers } \\
\text { (large). } \\
\text {-Relational QM } \\
\text { measures } \\
\text { included } \\
\text { extended } \\
\text { enterprise QM } \\
\text { measures (for } \\
\text { partnering with } \\
\text { suppliers and } \\
\text { customers on } \\
\text { large projects). }\end{array}$ & $\begin{array}{l}\text { QM practices } \\
\text { enabling } \\
\text { alignment: } \\
\text {-Emphasis on } \\
\text { alignment } \\
\text { using relational } \\
\text { customer QM } \\
\text { measures } \\
\text { based on large } \\
\text { long run } \\
\text { projects } \\
\text { (qualitative } \\
\text { and } \\
\text { quantitative } \\
\text { QM } \\
\text { measures). } \\
\text {-QM sets } \\
\text { based on } \\
\text { managing } \\
\text { predicted or } \\
\text { lead customer } \\
\text { needs in } \\
\text { relation to } \\
\text { alignment. } \\
\text {-Joint } \\
\text { relational QM } \\
\text { alignment } \\
\text { setting with } \\
\text { key customers. }\end{array}$ & $\begin{array}{l}\text { QM practices } \\
\text { enabling } \\
\text { alignment: } \\
\text {-Lack of } \\
\text { customer } \\
\text { segmentation } \\
\text { QM measures } \\
\text { to support } \\
\text { alignment } \\
\text { actions. } \\
\text {-Prescriptive } \\
\text { transactional } \\
\text { set of } \\
\text { alignment QM } \\
\text { measures for } \\
\text { customers of } \\
\text { all sizes } \\
\text { resulting in } \\
\text { lack of context } \\
\text { based } \\
\text { alignment. } \\
\text {-Increased } \\
\text { focus on } \\
\text { innovation QM } \\
\text { measures for } \\
\text { innovative } \\
\text { service } \\
\text { delivery for } \\
\text { some key } \\
\text { markets. }\end{array}$ \\
\hline
\end{tabular}

